\title{
Quality of life of elderly quilombolas in the Brazilian northeast
}

\section{Abstract}

Objective: To evaluate the quality of life (QoL) of elderly quilombolas (residents of quilombo settlements first established by escaped slaves) in mixed urban and rural residential developments (agrovilas) in Alcântara, Maranhão, Brazil. Method: An observational, crosssectional and descriptive study was performed. The sample consisted of 129 elderly people of both genders, aged 60 years or older and living in northeastern Brazil. The sample was allocated into three groups, distributed according to geographic space. Quality of life was assessed using the WHOQoL-Bref instrument and a sociodemographic questionnaire was applied. The comparison between groups was carried out using the Anova test (one-way) and subsequently the Bonferroni Post-Hoc test. The correlation was obtained by the Pearson test, $p<0.05$. Results: Elderly quilombolas had a mean age of 69.7 years $( \pm 7.9)$ and were predominantly men with low income and schooling. Quality of life had higher scores in the social domain (values) and lower in the environmental domain (values). Quality of life as measured by the psychological domain was higher in group I than in groups II $(p=0.012)$ and III $(p=0.002)$. The facets of QoL correlated with facets of health for group I $(\mathrm{r}=0.357 ; p=0.032)$ and III $(\mathrm{r}=0.461 ; p<0.001)$. Conclusion: The situation of the quilombola population surveyed is considered vulnerable and psychological factors influence QoL.

\footnotetext{
Universidade Federal do Maranhão (UFMA), Programa de Pós-graduação em Saúde e Ambiente. São Luís, Maranhão, Brasil.

2 Universidade de São Paulo (USP), Programa Interunidades de Pós-Graduação de Doutoramento em Enfermagem, Escola de Enfermagem de Ribeirão Preto (EERP). Ribeirão Preto, São Paulo, Brasil.

3 Universidade Estadual Paulista Júlio de Mesquita Filho (UNESP), Programa de Pós- Graduação em Ciências da Motricidade, Faculdade de Ciências e Tecnologia. Presidente Prudente, São Paulo, Brasil.

\author{
Ana Hélia de Lima Sardinha' ${ }^{1}$ \\ Francisca Bruna Arruda Aragão2 (ID \\ Cleidson Morais Silval \\ Zulimar Márita Ribeiro Rodrigues' (ID) \\ Andréa Dias Reis ${ }^{3}$ (D) \\ István van Deursen Varga'
}

Keywords: Health of the Elderly. African Continental Ancestry Group. Quilombolas. Quality of Life. 


\section{INTRODUCTION}

The quilomba (residents of quilombo settlements originally established by escaped slaves) population is vulnerable to diseases that include social aspects, both at different stages of life and on an individual basis ${ }^{1}$. The situation of vulnerability experienced by the black population in Brazil was recognized by the Brazilian federal government when it created the Special Secretariat of Racial Equality Promotion Policies (or Seppir) in 2003²; through the Brazil Quilomba Program in 2004; and with the establishment of the National Policy of the Integral Health of the Black Population (or PNSIPN) in $2009^{2}$. This emphasizes the need to guarantee and expand the access of the rural population, particularly quilomba populations, to health actions and services ${ }^{2}$.

The process of the official institutional recognition of a quilomba community by the Brazilian State begins with the community's own self-identification as such, through territory, social relations and specific cultural manifestations, with the inference of African heredity and memories of the resistance to the historical oppression suffered ${ }^{3,4}$.

According to the Palmares Cultural Foundation ${ }^{5}$, Maranhão has the second largest number of certified quilomba communities among Brazilian states, with a total of 492 (the largest is Bahia, with 638). Among the municipal regions of Maranhão, Alcântara has the largest number of communities, with a total of 79 . For the Association of Rural Black Quilomba Communities of Maranhão (or Aconeruq) quilombas still struggle to secure basic rights such as access to health, formal education, vocational training, improved working conditions and income generation ${ }^{6}$.

In Alcântara, between 1986 and 1987, 312 families suffered the loss of their territory when they were transferred to seven agrovilas (mixed urban and rural residential developments) created by the Brazilian Air Force at the time of the establishment of the Alcântara Launch Center (ALC): Espera, Cajueiro, Ponta Seca, Só Assim, Pepital, Marudá and Peru' ${ }^{7,8}$. Previous research ${ }^{6-8}$ on the quilomba territories of Alcântara showed the transformations and impacts that occurred as a result of the resettlement in agrovilas; however, there was no discussion about the quality of life (QoL), especially of the elderly who experienced the entire process of loss of their territories.

The World Health Organization (WHO) defines QoL as “an individual's perception of their position in life, in the context of the culture and value systems in which they live, and in relation to their goals, expectations, standards and concerns".

The objective of this study was to evaluate the QoL of the elderly quilombas of the agrovilas of Alcântara, Maranhão, describing their sociodemographic characteristics and considering the general facets and the physical, psychological, social relations and environment domains.

\section{METHOD}

This is an observational, cross-sectional and descriptive study carried out in the urban area of Alcântara, Maranhão, Brazil, in the agrovilas created by the Brazilian Air Force.

The survey was conducted between June and December 2012 by a team of five healthcare professionals (one nurse, three nursing technicians and one pharmacist) who were previously trained to collect data.

The total number of elderly persons and their addresses in each of the agrovilas were obtained through home visits made by community health agents of the Family Health Strategy (FHS). The total population of the agrovilas is approximately 1,600 inhabitants. Based on this number, the sample size was calculated using the StatCalc tool of the Epi Info 7 statistical program, considering a prevalence of elderly persons of around 5\% to $9 \%$ and a confidence interval (CI) of $95 \%$, reaching a value of 117 . A further $10 \%$ was added to this figure as a correction factor for possible losses.

The agrovilas were grouped by size and geographical proximity, resulting in their division into three groups, as follows: Group I: Ponta Seca, Cajueiro, Espera; Group II: Só Assim, Pepital, Marudá and Group III: Peru. A total of 129 questionnaires 
were applied, with Group I containing 36 elderly persons, Group II 48 and Group III 45. There were 22 ineligible individuals, 11 of whom were unable to be located, six of whom were traveling and five who were unable to respond. The final sample calculation was 129 individuals.

The approach to the elderly began with the application of the Mini Mental State Examination to assess the cognitive conditions of those eligible to communicate with the researcher and consent to participation in the interviews. After this step, the objectives and procedures of the research were explained, as well as the request to sign a Free and Informed Consent Form, followed by interviews at the homes of the participants.

Quality of life was assessed using the World Health Organization Quality of Life-Bref questionnaire (WHOQoL-Bref), a version which was created from the WHOQoL-100 to allow easier application, as it is brief, convenient and accurate. The questionnaire consists of four domains (physical, psychological, social relations and environment) with 24 facets, and two general facets about self-assessment of QoL, through the questions: "How would you rate your quality of life?" (Quality of life facet) and "How satisfied are you with your health?" (overall health facet). The WHOQoL-Bref has five response options (ranging from 1 to 5 ) on a Likert scale ${ }^{9}$.

The WHOQoL-Bref has three modes of administration: self-reported, assisted by the interviewer and administered by the interviewer, the latter of which was adopted by the researchers in the present study. The interviewer read the instructions, the questions and the answer scale descriptors and marked the answer given by the participant. A questionnaire adapted by the researcher with closed questions was also applied to identify socioeconomic level (main source of income; family income).
Data were presented as mean, standard deviation, absolute and relative frequency. One-way Anova test was used to compare intergroup means, after which Bonferroni's Post-Hoc test was applied to verify which of the groups differed from one another. Pearson's test was also applied for analysis of the correlation between the general facets of QoL and the perception of the QoL domains. Data were analyzed using the Statistical Package for Social Science (SPSS) version 2.0 , considering $\alpha=5 \%$, or in other words $p<0.05$.

The study was approved by the Research Ethics Committee of the Universidade Federal do Maranhão under $\mathrm{n}^{\circ}$ 23115-017526 dated 01.03.2012.

\section{RESULTS}

The research sample consisted of 129 elderly quilombas (Group I $=36$ elderly persons, Group II $=48$ and Group III = 45).

The sociodemographic characteristics of the elderly agrovila residents are shown in Table 1. A total of $96.1 \%$ were black or brown skinned and men represented $51.9 \%$ of the population. Women were the majority in Groups I (52.8\%) and III (66.7\%). Illiteracy predominated in all groups, with high percentage values.

Table 2 shows the values of the four WHOQoLBref domains (physical, psychological, social relations and environment) by means and standard deviation, considering a scale of $0-100$. The social relations average scores had the highest percentage values among the four domains analyzed for all the studied agrovilas.

The results summarized in Table 3 show the facets that explain the differences in Group I, which had different means and lower perception in the psychological domain. 
Table 1. Sociodemographic characterization of elderly quilombas (N=129). Alcântara. Maranhão, 2012.

\begin{tabular}{|c|c|c|c|}
\hline Variables & $\begin{array}{l}\text { Group I } \\
\mathrm{n}(\%)\end{array}$ & $\begin{array}{l}\text { Group II } \\
\mathrm{n}(\%)\end{array}$ & $\begin{array}{l}\text { Group III } \\
\mathrm{n}(\%)\end{array}$ \\
\hline \multicolumn{4}{|l|}{ Ethnic Group/Color } \\
\hline White & 0 & $1(2.1)$ & $3(6.7)$ \\
\hline Black & $29(80.6)$ & $19(39.6)$ & $11(24.4)$ \\
\hline Brown-skinned & $7(19.6)$ & $27(56.2)$ & $31(68.9)$ \\
\hline Indigenous & 0 & $1(2.1)$ & 0 \\
\hline \multicolumn{4}{|l|}{ Gender } \\
\hline Male & $17(47.3)$ & $35(72.9)$ & $15(33.3)$ \\
\hline Female & $19(52.8)$ & $13(27.1)$ & $30(66.7)$ \\
\hline Average age (years) (standard deviation) & $65.77( \pm 7.3)$ & $65.44( \pm 6.4)$ & $71.40( \pm 9.8)$ \\
\hline \multicolumn{4}{|l|}{ Schooling } \\
\hline Illiterate & $22(61.1)$ & $31(64.6)$ & $25(55.6)$ \\
\hline Incomplete primary education & $11(30.6)$ & $17(35.4)$ & $17(37.8)$ \\
\hline Complete primary education & $2(5.6)$ & 0 & $2(4.4)$ \\
\hline Complete secondary school education & 0 & 0 & $1(2.2)$ \\
\hline Graduate & $1(2.7)$ & 0 & 0 \\
\hline $\begin{array}{l}\text { Average income (minimum wage: } \mathrm{R} \$ 622.00 \text { ) } \\
\text { (standard deviation) }\end{array}$ & $1.92( \pm 0.6)$ & $1.58( \pm 0.8)$ & $1.53( \pm 0.5)$ \\
\hline \multicolumn{4}{|l|}{ Marital status } \\
\hline Not married & $10(27.7)$ & $10(20.8)$ & $10(22.2)$ \\
\hline Married & $13(36.1)$ & $24(50.0)$ & $17(37.8)$ \\
\hline Widower & $11(30.6)$ & $12(25.0)$ & $16(35.6)$ \\
\hline Separated & $2(5.6)$ & $2(4.2)$ & $2(4.4)$ \\
\hline
\end{tabular}

Table 2. Comparison between domains of quality of life of elderly quilombas (N=129). Alcântara, Maranhão, 2012.

\begin{tabular}{lllll}
\hline Domains & $\begin{array}{l}\text { Group I } \\
\text { Mean }( \pm \mathrm{sd})\end{array}$ & $\begin{array}{l}\text { Group II } \\
\text { Mean }( \pm \mathrm{sd})\end{array}$ & $\begin{array}{l}\text { Group III } \\
\text { Mean }( \pm \mathrm{sd})\end{array}$ & $p$ \\
\hline Physical & $56.7( \pm 12.9)$ & $58.3( \pm 14.0)$ & $61.4( \pm 12.4)$ & 0.257 \\
Psychological & $54.7( \pm 13.1)$ & $62.0( \pm 9.7)^{\mathbf{a}}$ & $63.3( \pm 10.9)^{\mathbf{a}}$ & 0.002 \\
Social relations & $73.8( \pm 10.8)$ & $71.0( \pm 9.9)$ & $73.1( \pm 3.9)$ & 0.279 \\
Environment & $49.8( \pm 11.9)$ & $49.2( \pm 7.8)$ & $52.4( \pm 7.6)$ & 0.220 \\
\hline
\end{tabular}

${ }^{a}$ Differed from Group I.

Table 3. Facets of the psychological domain in elderly quilombas (N=129). Alcântara, Maranhão, 2012.

\begin{tabular}{llll}
\hline Facets & $\begin{array}{l}\text { Group I } \\
(\mathrm{n}=36)\end{array}$ & $\begin{array}{l}\text { Group II } \\
(\mathrm{n}=48)\end{array}$ & $\begin{array}{l}\text { Group III } \\
(\mathrm{n}=45)\end{array}$ \\
\hline How much do you enjoy life? & 2.72 & 3.19 & 2.87 \\
To what extent do you think your life has meaning? & 3.25 & 3.63 & 3.78 \\
How much can you concentrate? & 3.25 & 3.21 & 3.22 \\
Can you accept your physical appearance? & 3.06 & 2.92 & 3.13 \\
How satisfied are you with yourself? & 3.89 & 3.75 & 3.78 \\
How often do you have negative feelings such as & & & 4.42 \\
moodiness, despair, anxiety, depression? & 2.97 & 4.19 & \\
\hline
\end{tabular}


Table 4 shows the mean scores and standard deviation for the overall QoL and health facets of the three groups analyzed. Group III had the highest scores of 3.3 and 3.1 and Group II the lowest of 3.0 and 2.9 .

The results of the correlations for the WHOQoLBref quantitative variables, taken two at a time between the two overall QoL facets and perception of health and between each of the overall facets and the four domains, are also shown in Table 4.

In Group I there were positive and significant correlations between the facets of QoL and health $(\mathrm{r}=0.357 ; p=0.032)$, as well as facets of health with the physical ( $\mathrm{r}=0.615 ; p<0.001)$, psychological $(\mathrm{r}=0.447 ; p=0.006)$ and environment $(\mathrm{r}=0.486$; $p=0.003)$ domains. Group II exhibited a positive and significant correlation between the health facet and the physical domain of QoL ( $r=0.462$; $p=0.001)$. Group III also exhibited several positive and significant correlations, which were: between QoL facets and bealth ( $\mathrm{r}=0.461 ; p<0.001)$, QoL facet with the environmental domain $(\mathrm{r}=0.358 ; p=0.016)$, and the health facet with the physical $(\mathrm{r}=0.591 ; p<0.001)$ and the environment domains $(\mathrm{r}=0.375 ; p=0.011)$ of QoL (Table 4). 


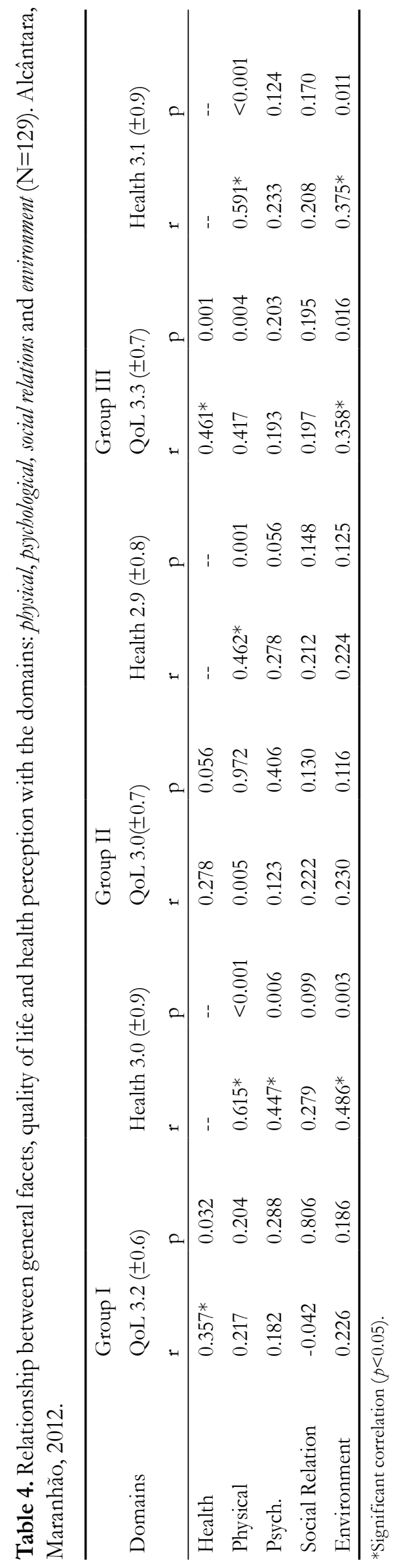




\section{DISCUSSION}

The agrovilas had a mostly black population. In comparison to white Brazilians, blacks have greater exposure to factors that affect both QoL and self-rated health perception, such as inferior socioeconomic status, worse living conditions and housing, higher rates of contracting infectious parasitic diseases, and greater exposure to situations of sexual, physical and psychological violence ${ }^{1,4}$.

In terms of composition by gender, there was a predominance of men in the overall total. Thus, the demographic profile was different from the communities surveyed in Paraíba ${ }^{10}$ and $\mathrm{Bahia}^{4}$, where women predominated. It should be noted that the 2010 Census data ${ }^{11}$ corroborate the predominance of the male population in the rural and urban areas of Alcântara, with 8,044 and 3,214 people respectively. Regarding age, there was a low frequency of octogenarians and nonagenarians compared to sexagenarians and septuagenarians, and the population can therefore be considered young elderly.

The three groups had an illiteracy rate of around $60 \%$, far above the national rate of $26.5 \%$ in the population aged 60 and over ${ }^{11}$. According to the Brazilian Institute of Geography and Statistics $(\mathrm{IBGE})^{11}$, illiteracy rates in Maranhão for black and brown-skinned persons aged 60 years or older total $62.2 \%$ and $56.9 \%$, respectively. Regarding the first group, the rate in the state of Maranhão was surpassed only by that of Piauí, with 67.8\%; Alagoas, with 66.4\%; and Paraíba, with 63.6\%. In the second group it was surpassed by Alagoas, $59.6 \%$, and Piauí, with $58.4 \%$.

There was a predominance of married individuals in the three groups, followed by widowers. In a study by Vieira and Monteiro ${ }^{12}, 75 \%$ of people were found to be single, but with the status of married by common law. The authors also point out that until recently there was no civil registration among older quilombas, which can be explained by the low social income of this population.

Family income among the three groups was similar and ranged from one to two minimum wages, considering standard deviation. Several studies have identified low incomes in quilomba communities, quantifying an income of half minimum salary and minimum salary $y^{4,12,13}$, or describing occupational activities such as small-scale agriculture ${ }^{10}$, subsistence farming and domestic help work ${ }^{14}$, which presupposes a low income. The family income of the elderly quilombas of the present study was higher than that found in literature (half a minimum wage), which may be due to a commercial income from handicrafts, in addition to social benefits ${ }^{4,12,13}$. The overall conditions of the elderly surveyed are similar to other Brazilian quilomba communities, as stated by Cabral-Miranda et al. ${ }^{15}$. These groups are located in rural areas and in conditions of social and health inequality, as they live in remote areas with difficulties in accessing health and education services.

These communities were originally located near the coast and had fishing as one of their main sources of food. The agrovilas are now located between 10 and $21 \mathrm{~km}$ away from the sea, making fishing impracticable.

The distance from the sea and the unfeasibility of fishing add to the difficulties in access to health, education and leisure services. The difficulties of accessing the public health service show the vulnerable situation of quilomba communities, especially of the elderly persons surveyed. In addition to the high rate of illiteracy among the elderly, there is an urgent need to implement adult literacy programs which, although envisaged in the Brazil Quilomba Program, have not yet implemented most of the proposed actions.

The psychological domain differed statistically between the groups. In Group I a predominance of self-declared black (80.6\%) and illiterate (61.1\%) individuals had the worst averages. In this group, average scores in the facets that make up this domain were lower than in the other groups; this indicates the need for actions aimed at the mental health of participants and, in particular, an investigation and approach to depression-related disorders.

Of the groups analyzed, Group III had the best averages in both overall facets. However, all groups have compatible socioeconomic and cultural realities, which would tend to make them similar. 
The social relations domain had the highest average score for each of the analyzed groups, while the environment domain was the worst evaluated in all groups. A similar result was detected in quilomba communities in the state of Sergipe ${ }^{16}$.

It is assumed that the high scores in the social relations domain, which is composed of the social relations, social support and sexual activity facets, were because this domain has the fewest facets and also because the highly social organization of the communities are strongly marked by kinship, offering greater social support to the elderly. Santos et al. ${ }^{16}$ suggest that family and social ties are strong in quilomba communities and explain the higher averages of the social domain.

The environment domain received the worst evaluation by all the agrovilas. A likely explanation for such a poor perception may be a consequence of the compulsory resettlement process described earlier. The process of compulsory resettlement has had a negative impact on communities and, more than 30 years later, the impacts on the lives of those who are forced to resettle are still felt and remembered. The loss of their former dwelling places can be better understood by the analysis of Duprat ${ }^{17}$, which claims that the land is the bond of union of the group and allows its temporal continuity across successive generations, preserving its culture and particular way of life.

The process of resettlement to the agrovilas made it impossible to practice the traditional fishing, hunting, extractive activities and agriculture that guaranteed the self-sufficiency of the communities. In return, the peasants received small, poorly fertile, eroded plots. In a general analysis of the creation of the seven agrovilas and their impacts, Clímaco ${ }^{8}$ identified several authors who reported instability, discontent and negative repercussions among the Alcântara quilombas.

The psychological domain was the only one to identify statistically significant differences in the means of the three groups, with Group I having the worst average in the following facets: "How much do you enjoy life?" - positive feelings, "To what extent do you think your life makes sense?" - spirituality/religiosity/personal beliefs and "How often do you have negative feelings such as moodiness, despair, anxiety and depression?" - negative feelings. It can be inferred that this domain is directly related to the perception and presence of depression.

The social relations domain achieved the highest average scores. Conversely, Santos et al. ${ }^{16}$ found little difference in the social relations and psychological domains, reporting hypertension and QoL in quilombas. Assis et al. ${ }^{18}$ identified worse averages for the psychological domain in retired or pensioner quilombas and women.

The physical domain showed no statistical difference between the groups, which may be related to age group. One possible explanation for the satisfaction identified in this domain may be average age (young elderly persons), as the functional capacity of the elderly has not yet been impaired and positively influences the perception of QoL. Assis et al. ${ }^{18}$ observed a correlation between age and the physical domain among quilomba communities investigated in Sergipe.

The overall facet scores of the groups were related, however Group I stood out due to having more correlations between the health facet and the different QoL domains. A study on sanitary and health conditions in quilombas identified low QoL due to the absence of basic sanitation and health services ${ }^{4,10}$. Due to the subjectivity and multidimensionality of the meaning of QoL, evaluation and comparison with other quilomba studies and/or groups becomes even more complex. Even among the seven surveyed agrovilas, which had very similar realities, the polysemy of the expression QoL may explain the inequalities in the evaluation between the groups.

In general, studies that assess quilomba health and/or QoL are still scarce ${ }^{4}$, as stated by Santos et al. ${ }^{16}$. Demonstrating the incipient nature of quilomba research therefore contradicts one of the goals of the PNSIPN, which is to foster studies and research on racism and the health of the black population. It is also a challenge to the process of implementation and improvement of the PNSIPN ${ }^{17}$.

Due to the aforementioned aspects, the present study had some limitations, as no other parameters that may be related to QoL were evaluated. The WHOQoL-Bref instrument used, however, allows 
a deeper investigation of QoL. The difficulties experienced by researchers when accessing the Alcântara agrovilas to carry out the research is also notable, in many cases justifying the low academic production on quilomba communities.

\section{CONCLUSION}

The study found a predominance of men in relation to women, and a prevalence of young elderly persons with an average age of 67 years, who were married and/or widowed, and had low education levels and income. The WHOQoL-Bref instrument identified social relations as the best evaluated domain and environment as the worst.

It is inferred that the positive evaluation of the social relations domain by the elderly largely reflects the strength of the affective and kinship ties, cultures and practices of solidarity of these quilomba communities. Among traditional peoples and communities, respect for and protection of the elderly is generally still a feature. The cultural apparatus must always be considered in research and public policies that target ethnic groups with entrenched traditions.

The environmental domain proved to be the most worrying, given the low averages identified in all the agrovilas. The resettlement process in these agrovilas directly interfered with the low QoL assessment in this domain. In part, this low assessment may confirm the research assumption - that the process of compulsory resettlement has negatively impacted communities and is still felt and remembered by the elderly.

Finally, the physical domain was well evaluated. A likely explanation for this level of satisfaction is age range, since there was a predominance of young elderly persons in the agrovilas, who therefore had an active functional capacity. However, this situation can be reversed considering the lack of integrative public policies aimed at health promotion.

The situation of the quilomba population surveyed is considered to be worrying, given the institutional vulnerability identified, in addition to aspects assessed related to difficulties of access to services and frequent deficiency or even lack of implementation of policies aimed at health promotion, access to drinking water, sanitation, education, environmental protection and recovery, among others. It is noteworthy that in a state like Maranhão, where the majority of the population is black, several aspects of the National Policy for the Integral Health of the Black Population (or PNSIPN) have not been properly implemented, highlighting its deficiencies and the challenges to be addressed.

\section{REFERENCES}

1. Cardoso CS, Melo LO, Freitas DA. Condições de saúde nas comunidades quilombolas. Rev Enferm UFPE [Internet]. 2018 [acesso em 18 jun. 2019];12(4):1037-45. Disponível em: https://periodicos.ufpe.br/revistas/ revistaenfermagem/article/viewFile/110258/28665

2. BRASIL. Ministério da Saúde. Política nacional de saúde integral da população negra: uma política do SUS [Internet]. Brasília, DF: MS; 2017 [acesso em 28 jun 2019]. Disponível em: http://bvsms.saude. gov.br/bvs/publicacoes/politica_nacional_saude_ populacao_negra_3d.pdf

3. Chehuen Neto JA, Fonseca GM, Brum IV, Dos Santos JLCT, Rodrigues TCGF, Paulino KR, et al. Política nacional de saúde integral da população negra: implementação, conhecimento e aspectos

socioeconômicos sob a perspectiva desse segmento populacional. Ciênc Saúde Colet [Internet]. 2015 [acesso em 17 jun. 2019];20(6):1909-16. Disponível em: http://www.scielo.br/scielo.php?pid=S141381232015000601909\&script $=$ sci_abstract\&tlng=pt

4. Bezerra VM, Medeiros DS, Gomes KO, Souzas R, Giatti L, Steffens, et al. Inquérito de Saúde em Comunidades Quilombolas de Vitória da Conquista, Bahia, Brasil (Projeto COMQUISTA): aspectos metodológicos e análise descritiva. Ciênc Saúde Colet [Internet]. 2014 [acesso em 06 jan. 2015];19(6):1835-47. Disponível em: http://www. scielo.br/scielo.php?script $=$ sci_arttext\&pid=S141381232014000601835\&lng=pt. http://dx.doi. org/10.1590/1413-81232014196.01992013 
5. Fundação Cultural Palmares. Quadro geral de comunidades remanescentes de quilombos (CRQs) [Internet]. Brasília, DF: [sem editora]; 2015 [acesso em 14 maio 2015]. Disponível em: http://www.palmares. gov.br/wp-content/uploads/crqs/quadro-geral-porestado-ate-23-02-2015.pdf

6. Paixão RMM. Enriba daterra: da sinergia da luta individual para a coletiva, refletindo a partir do quilombo de Cana Brava [Dissertação na Internet]. São Luíz: Universidade Estadual do Maranhão; 2015 [acesso em 18 jun. 2019]. Disponível em: http://www.ppgcspa.uema.br/wp-content/ uploads/2016/06/DISSERTA\%C3\%87\%C3\%83OMAUR $\%$ C3\%8DCIO-PAIX $\%$ C3\%83Overs $\% \mathrm{C} 3 \% \mathrm{~A} 3 \mathrm{o}$-final-29.10.2015-com-inclus $\% \mathrm{C} 3 \% \mathrm{~A} 3 \mathrm{o}-$ de-sugest $\% \mathrm{C} 3 \% \mathrm{~B} 5$ es-da-Banca-revisada-LilianGomes-e-configurado-por-Lilian-Bernardes-3.pdf

7. Viegas DP, Varga IVD. Promoção à saúde da mulher negra no povoado Castelo, Município de Alcântara, Maranhão, Brasil. Saúde Soc [Internet]. 2016 [acesso em 17 jun. 2019];25(3):619-30. Disponível em: http:// www.scielo.br/pdf/sausoc/v25n3/1984-0470sausoc-25-03-00619.pdf

8. Clímaco VDN. Territórios sociais de resistência em comunidades de remanescentes de quilombos. Rev Desenv Reg [Internet]. 2015 [acesso em 15 jun. 2019];12(1):89-100. Disponível em: file://D:/ REVIS\%C3\%83O\%20DE\%20TEXTOS/2019/ BRUNA $\% 20$ ARAG $\%$ C3\%83O/ARTIGO $\% 20$ 11.06.19/CORRE $\%$ C $3 \% 87 \%$ C $3 \% 83 \mathrm{O} \% 20$ ARTIGO/NOVOS\%20ARTIGOS\%20PARA\%20 SUBSTITUIR/222-466-2-PB.pdf

9. World Health Organization. Quality of life assesment group: development of the world health organization whoqol-bref quality of life assesment. Soc Sci Med. 1995;41:1403-9.

10. De Oliveira SM, Menezes Junior JO, Da Silva Junior SV, Dias MD, Fernandes MGM, Ferreira Filha MO. Rodas de terapia comunitária: construindo espaços terapêuticos para idosos em comunidades quilombolas. Rev Enferm UFSM [Internet]. 2017[acesso em 15 jun. 2019];7(4):712-24. Disponível em: https://periodicos. ufsm.br/reufsm/article/view/20299/pdf

11. Instituto Brasileiro de Geografia e Estatística. Síntese de indicadores sociais: uma análise das condições de vida da população brasileira 2010 [Internet]. Rio de Janeiro: IBGE; 2010 [acesso em 25 out. 2011]. Disponível em: www.ibge.gov.br
12. Vieira ABD, Monteiro PS. Comunidade quilombola: análise do problema persistente do acesso à saúde, sob o enfoque da bioética de intervenção. Saúde Debate. 2013 [acesso em 8 jan. 2014];37(99):610-8. Disponível: http://www.scielo.br/scielo.php?script $=$ sci_ arttext\&pid=S0103-11042013000400008\&lng=pt\&nr $\mathrm{m}=$ iso\&tlng $=\mathrm{pt}$

13. Freitas IA, Rodrigues ILA, Silva IFS, Nogueira LMV. Perfil sociodemográfico e epidemiológico de uma comunidade quilombola na Amazônia Brasileira. Rev Cuid [Internet]. 2018 [acesso em 16 jun. 2019];9(2):2187-200. Disponível em: http:// www.scielo.org.co/pdf/cuid/v9n2/2346-3414cuid-9-2-2187.pdf

14. Luiz JM. Quilombolas de caiana dos crioulos (alagoa grande - PB): memória, etnicidade e autoconsciência cultural. Rev ABPN [Internet]. 2018 [acesso em 15 jun. 2019];10(Ed. Esp.):435-64. Disponível em: http://www.abpnrevista.org.br/revista/index.php/ revistaabpn1/article/view/477

15. Cabral-Miranda G, Dattoli VCC, Dias-Lima A. Enteroparasitos e condições socioeconômica e sanitárias em uma comunidade quilombola do semiárido baiano. Rev Patol Trop [Internet]. 2010. [acesso em 05 jun. 2013];39(1):48-55. Disponível em: http://www.revistas.ufg.br/index.php/iptsp/article/ view/9498

16. Santos VC, Boery EN, Pereira R, Rosa DOS, Vilela ABA, Dos Anjos KF, et al. Socioeconomic and health conditions associated with quality of life of elderly quilombolas. Texto \& Contexto Enferm [Internet]. 2016 [acesso em 17 jun. 2019];25(2):1-9. Disponível em: http://www.revenf.bvs.br/pdf/tce/ v25n2/0104-0707-tce-25-02-1300015.pdf

17. Duprat D,organizador. Pareceres jurídicos: direitos dos povos e das comunidades tradicionais. Manaus: Documentos de Bolso; 2007.

18. Assis ES, Araújo JA, De Rezende MIRC, Oliveira CCC, Reis FPR, De Melo CM. Prevalence of variant hemoglobins and thalassemias in a maroon community in Sergipe, Brazil. Acta Sci [Internet]. 2015 [acesso em 18 jun. 2019];37(2):211-16. Disponível em: http://periodicos.uem.br/ojs/index.php/ ActaSciHealthSci/article/view/23444/pdf_92 